\title{
Forage seeding in rangelands increases production and prevents weed invasion
}

In a seeding study in the California foothills, annual ryegrass and soft brome performed well in the short term, and Flecha tall fescue, several hardinggrass varieties and Berber orchardgrass worked well in the long term.

by Josh S. Davy, Katherine Dykier, Tony Turri and Elise Gornish

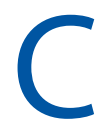
alifornia's foothill rangelands are an important source of fall, winter and spring forage for grazing livestock. Though the rangeland acreage represents a major component of California's land area, it is declining. The California Department of Conservation reports dryland farming and grazing acreage losses averaged nearly 54,000 acres per year from 1984 to 2010 (CDC 2014). This makes forage productivity increasingly important to help sustain livestock production in the state. Seeding of desirable plants may be a method to increase a forage base amidst shrinking land availability and increasing livestock lease rates (USDA NASS 2013). Other benefits of seeding productive grasses and herbs include reduced soil erosion (Jankauskas and Jankauskiene 2003; Malik et al. 2000), weed control (Wilson et al. 2010) and potentially enhanced soil carbon storage (Mapfumo et al. 2002).

\section{Scarce research on seeding forage}

A majority of the formal experimental research on improving nonirrigated rangeland (annual grassland, in particular) with seeded forage species in California

\section{Abstract}

Increasing forage productivity in the Sierra foothill rangelands would help sustain the livestock industry as land availability shrinks and lease rates rise, but hardly any studies have been done on forage selections. From 2009 to 2014, in one of the first long-term and replicated studies of seeding Northern California's Mediterranean annual rangeland, we compared the cover of 22 diverse forages to determine their establishment and survivability over time. Among the annual herbs, forage brassica (Brassica napus L.) and chicory (Cichorium intybus L.) proved viable options. Among the annual grasses, soft brome (Bromus hordeaceus) and annual ryegrass (Lolium multiflorum) performed well. However, these species will likely require frequent reseeding to maintain dominance. Long-term goals of sustained dominant cover (>3 years) are best achieved with perennial grasses. Perennial grasses that persisted with greater than $50 \%$ cover were Berber orchardgrass (Dactylis glomerata), Flecha tall fescue (Lolium arundinaceum) and several varieties of hardinggrass (Phalaris aquatica L., Perla koleagrass, Holdfast, Advanced AT). In 2014, these successful perennials produced over three times more dry matter (pounds per acre) than the unseeded control and also suppressed annual grasses and yellow starthistle (Centaurea solstitialis L.) cover. 
was completed before the 1970s. It focused largely on hardinggrass (Phalaris aquatica L.) (Kay 1969; Love 1951; Love et al. 1953; McKell et al. 1966; Miller et al. 1953; Miller et al. 1957; Stebbins 1950). The vast majority of other forages tested during that time failed, including other species of Phalaris, Idaho fescue (Festuca idahoensis Elmer), varieties of orchardgrass (Dactylis glomerata L.) and tall fescue (Schedonorus arundinaceus (Schreb.)).

Since that time, many forage varieties and species have become available but have not been experimentally tested. Most have been tried at the ranch level with results never reported. In one of the very few recent studies, Adams et al. (1999) compared the production of the nonnative perennial Berber orchardgrass to accessions of four California native perennial grasses. Except for a site characterized by a coastal influence, they found Berber to be $50 \%$ more productive (pounds per acre) than the average of the resident native perennials. Unfortunately, this is the only published rainfed trial in California foothill rangelands documenting forage production and cover comparisons since the 1970s. As a result, land managers lack data-driven recommendations of forage species and cannot adequately assess the efficiency or cost effectiveness of seeding.

\section{Seeding forage and weed control}

In addition to increasing forage production, seeding desirable forages may also suppress or prevent weed invasions. For example, James et al. (2015) found that combining forage seeding with other management approaches resulted in higher overall control of medusahead (Elymus caput-medusae L.) than using conventional control methods (prescribed fire, grazing, etc.) in isolation.

Intermountain trials with pubescent wheatgrass (Elytrigia intermedia) seedings have also proven successful for preventing yellow starthistle (Centaurea solstitialis L.) invasion (Enloe et al. 2005). The authors suggest that the perennial grass's late spring and early summer growth period coincided with the water use and growth period of starthistle, and that the grass

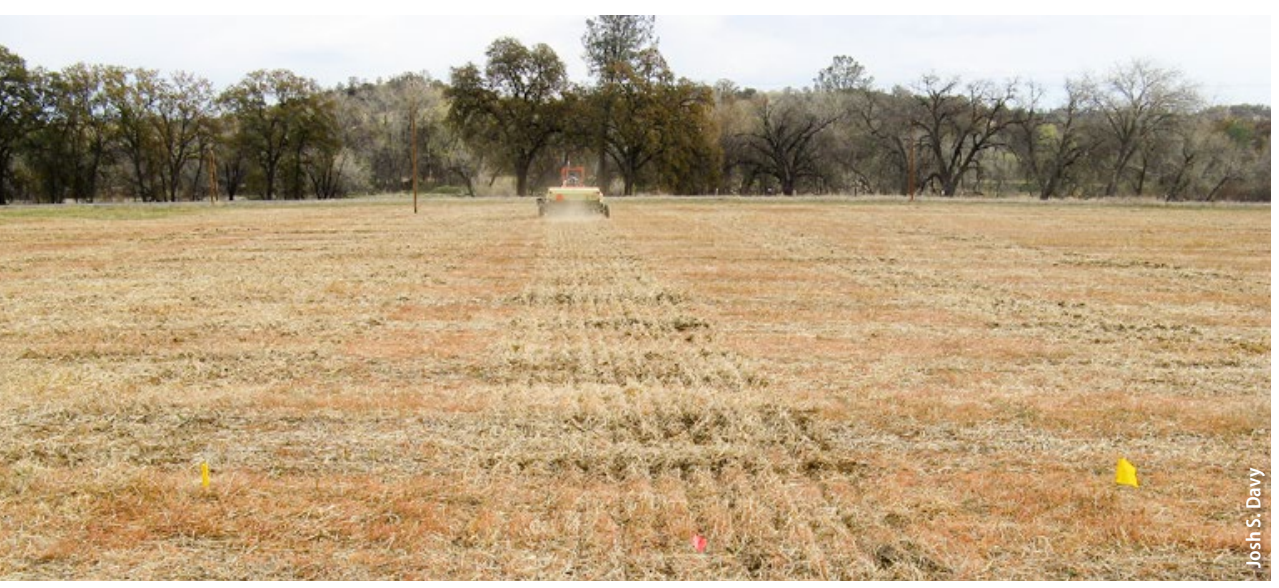

grew faster and gained competitive dominance for the limited late-season water supply. It did not appear that winter shading of emerging thistle seedlings was a competitive factor because pubescent wheatgrass lacked active winter growth, not differing in cover from the control until later in the season. Other research has found success in seeding both pubescent and crested wheatgrass (Agropyron cristatum (L.) Gaertn.) for weed suppression (Blank et al. 2015; Rose et al. 2001; Whitson and Koch 1998).

The utility of forage varieties in suppressing other species is likely specific to the climate in which they are grown. For example, in some cases, wheatgrasses have been shown to be ineffective in suppressing invasive annual grasses, because wheatgrasses lack winter season growth, which is needed to shade out the annual grasses (Borman et al. 1991; Roche et al. 1997).

In a maritime/Mediterranean climate in Oregon, Borman et al. (1991) reported that established stands of Berber orchardgrass were able to prevent the invasion of annual grasses. The authors noted that the perennial grass species that were most successful at suppressing annual grass invasion were those, like Berber orchardgrass, that initiated growth early in the season and continued growth through winter, causing winter shading. This contrast in the ability of different desirable grasses to maintain dominance over other plants highlights the importance of localized research to help ranchers select forages for seeding.

\section{Testing species in local conditions}

Borman et al. (1991) provided insight into the ability of forages to maintain a stand once established under a controlled, ideal environment; they transplanted grasses and allowed them to fully establish prior to any pressures of weed invasion. Our interest went further by evaluating the establishment process under a more common production scenario in a Northern California Mediterranean environment.

Norton et al. (2014) demonstrated the ability of new varieties of summer-dormant hardinggrass and Flecha tall fescue to withstand significant dehydration, a factor during the rainless California summers. This highlights them as important potential forage candidates, though the specific varieties tested have not been formally evaluated in California.

Other research has provided a too broad, or not necessarily applicable to California, overview of forage variety candidates. For example, though they are commonly available in California, little is known about the long-term survivability of orchardgrass cultivars (such as Kara and Paiute orchardgrass, which are commonly marketed as dryland grasses), except for the variety Berber. Herbaceous broad-leaved species such as chicory (Cichorium intybus L.), forage brassica (Brassica napus L.) and plantain (Plantago lanceolata L.) have been evaluated for use as forages with varying degrees of success in Australia and the U.S. Northeast (Reed et 


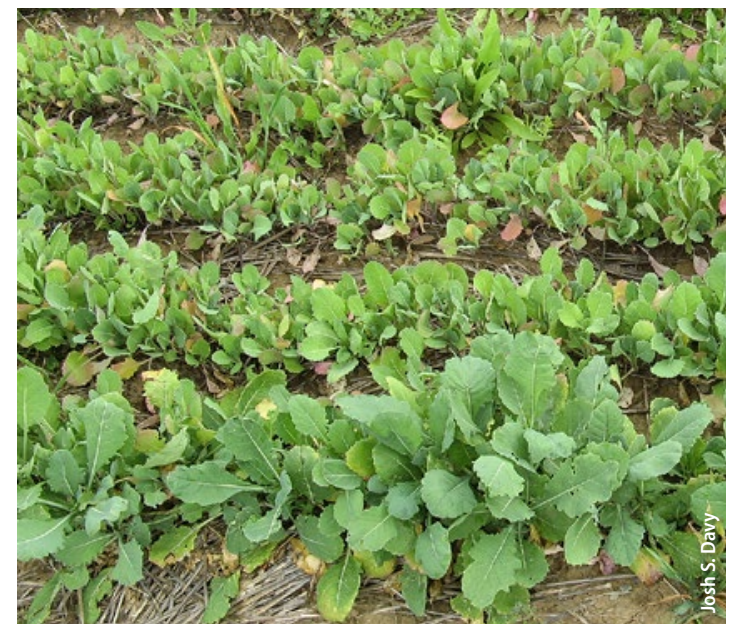

The annual herb Winfred forage brassica should be considered a single-season crop due to its lack of seed production.

al. 2008; Sanderson et al. 2003; Wiedenhoeft 1993) but not in California.

Up-to-date research that evaluates forage species for their ability to establish and survive in rainless summer conditions in Northern California does not exist. To address this limitation, we assessed the value of 22 types of forage for seeding, many of them not yet tested in California. We chose a group of forages that included different plant traits: native and nonnative, annual and perennial, summer dormant and winter dormant, broad-leaved species and grass species.

\section{Two experimental sites, soil types}

Trials were conducted in Paskenta, Tehama County, California, at an elevation of 725 feet, on alluvial soils. The two experimental sites were close in location but distinctly split by designations of Arbuckle and Tehama soil types (USDA NRCS 2015). Both sites were on nearly level terrain. Soil testing at the time of seeding showed organic matter and cation exchange capacity of 3.5\% and 13.2 in the Arbuckle soil, and 3.9\% and 22.1 in the Tehama soil, respectively. At a depth of 0 to 39 inches, the Tehama soil can store more water than the Arbuckle series (6.97 inches and 5.37 inches, respectively), due to the higher gravel content of the Arbuckle series. Both soils had a $\mathrm{pH}$ of 5.7. Both soils are considered extensive in the northern Sacramento Valley, making result comparisons practical to soils in foothill rangelands classified as three or higher.

The climate is Mediterranean, with mild, wet winters and rainless, hot summers. The rainfall season generally begins in late October and lasts through May. No rainfall occurs during summer months. Paskenta has a 30 -year average annual rainfall of 22.8 inches, though only in one of the five study years did rainfall reach that high. Growing season (July-July) rainfall totals were 24.07 inches in 2009-2010, 21.54 inches in 2010-2011, 15 inches in 2011-2012, 16.56 inches in 2012-2013 and 13.32 inches in 2013-2014 (Prism 2016). Following the
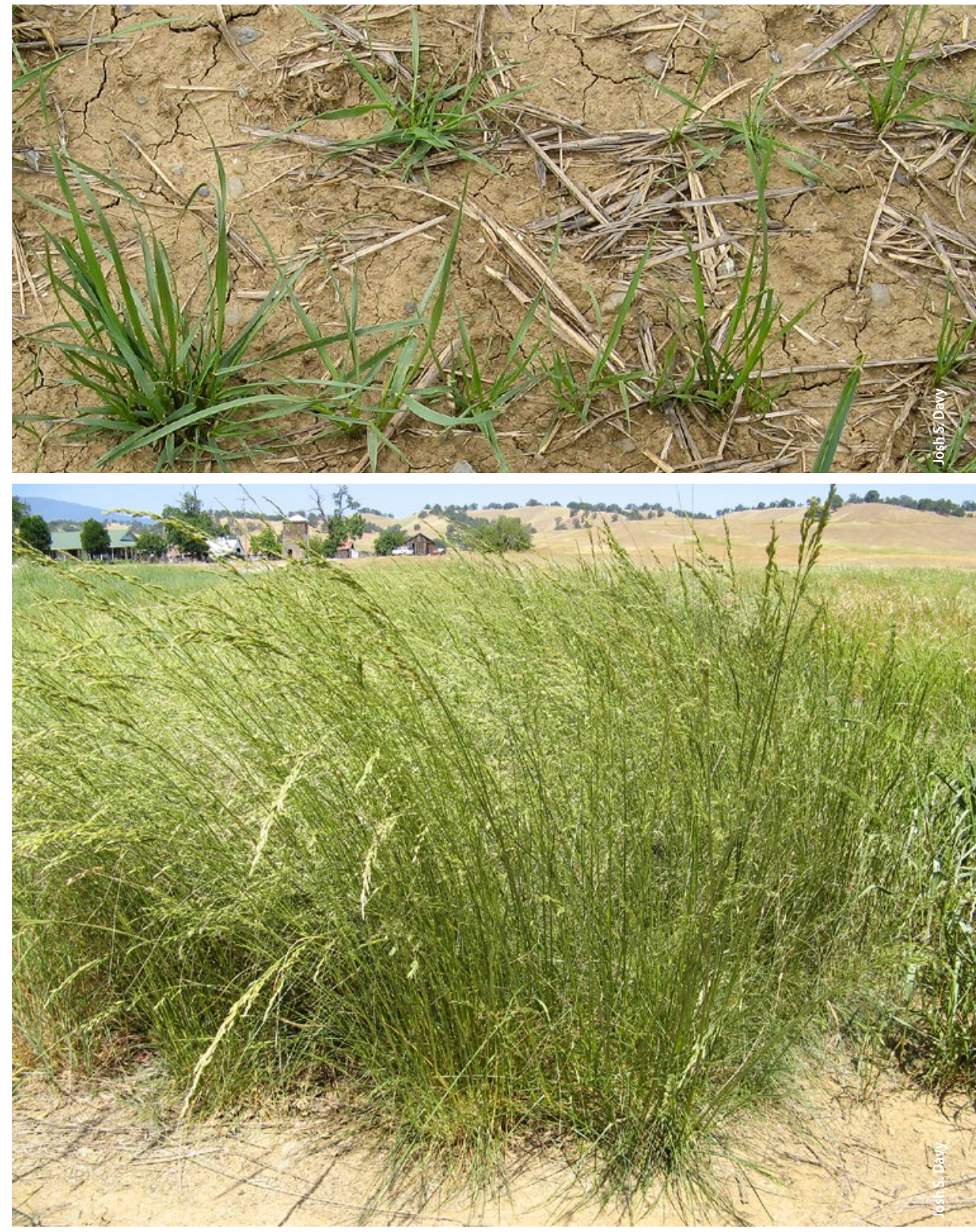

seasonal rainfall pattern, these rangelands are generally grazed as late fall, winter and spring pasture.

In 2014, the species cover in the control plot for both soil types averaged 36\% medusahead, 16\% yellow starthistle, $13 \%$ slender oat (Avena barbata Pott ex Link), $12 \%$ annual ryegrass, $6 \%$ ripgut brome (Bromus diandrus Roth), 6\% soft chess, $4 \%$ hare barley (Hordeum murinum L. subsp. leporinum (Link) Arcang.), 1\% filaree (Erodium cicutarium (L.) L'Hér. ex Aiton) and $1 \%$ rose clover (Trifolium hirtum All.).

Perennial grasses such as Flecha tall fescue produce abundant forage and also provide a more stable ground cover for a longer period than annuals. Top, seedling Flecha tall fescue at the end of the first growing season (May 2010); bottom, established Flecha tall fescue (May 2013).

\section{Seeding the plots}

The two trials were randomized complete block designs, on different soil types, with three replicates. Seeding included 22 types of perennial and annual grasses and herbs with unseeded controls (table 1). Each plot was 10 feet wide and 200 feet long. 
TABLE 1. Forages, seeding rate, seeding year and plants per square foot at establishment and in 2014

\begin{tabular}{|c|c|c|c|c|c|c|}
\hline \multirow{3}{*}{ Forage species, varieties } & \multirow{3}{*}{$\begin{array}{l}\text { Seeding } \\
\text { rate } \\
\\
\mathrm{lb} /\end{array}$} & \multirow{3}{*}{$\begin{array}{c}\text { Year } \\
\text { seeded } \\
\text { (fall) }\end{array}$} & \multicolumn{4}{|c|}{$\begin{array}{l}\text { Density in establishment } \\
\text { year and in } 2014\end{array}$} \\
\hline & & & 2010 & 2011 & 2012 & 2014 \\
\hline & & & & Plants/s & $\mathrm{ft}(\mathrm{SE})$ & \\
\hline \multicolumn{7}{|l|}{ Perennial grasses } \\
\hline \multicolumn{7}{|c|}{ Orchardgrass (Dactylis glomerata) } \\
\hline Berber & 5 & 2009 & $11(3.1)$ & & & $3(0.7)$ \\
\hline Paiute & 5 & 2009 & $14(2.0)$ & & & $0(0)$ \\
\hline Kara & 5 & 2009 & $9(1.1)$ & & & $0(0)$ \\
\hline \multicolumn{7}{|c|}{ Hardinggrass (Phalaris aquatica) } \\
\hline Perla koleagrass & 4 & 2009 & $11(1.2)$ & & & $3(0.4)$ \\
\hline Holdfast & 4 & 2010 & & $4(0.6)$ & & $2(0.4)$ \\
\hline Advanced AT & 4 & 2010 & & $4(0.6)$ & & $2(0.3)$ \\
\hline Australian II & 4 & 2010 & & $2(0.7)$ & & $1(0.3)$ \\
\hline \multicolumn{7}{|l|}{$\begin{array}{l}\text { Tall fescue (Schedonorus } \\
\text { arundinaceus (Schreb.)) }\end{array}$} \\
\hline Flecha & 5 & 2009 & $9(1.1)$ & & & $3(0.5)$ \\
\hline
\end{tabular}

Intermediate/pubescent wheatgrass (Elytrigia intermedia)

\begin{tabular}{|c|c|c|c|c|}
\hline Rush, intermediate & 15 & 2009 & $7(1.0)$ & $1(0.4)$ \\
\hline Luna, pubescent & 15 & 2010 & $4(0.6)$ & $1(0.4)$ \\
\hline \multicolumn{5}{|c|}{$\begin{array}{l}\text { all wheatgrass (Thinopyrum } \\
\text { onticum) }\end{array}$} \\
\hline Alkar & 15 & 2010 & $6(4.4)$ & $1(0.3)$ \\
\hline
\end{tabular}

Crested wheatgrass (Agropyron cristatum)

\begin{tabular}{|c|c|c|c|c|}
\hline Nordan & 15 & 2010 & $1(0.4)$ & $0(0)$ \\
\hline Hycrest & 15 & 2012 & $0(0)$ & $0(0)$ \\
\hline Douglas & 15 & 2012 & $0(0)$ & $0(0)$ \\
\hline $\begin{array}{l}\text { een wheatgr } \\
\text { ffmannii)* }\end{array}$ & & & & \\
\hline Saltlander & 15 & 2012 & $0(0)$ & $0(0)$ \\
\hline
\end{tabular}

Blue wildrye (Elymus glaucus)

Anderson

15

2010

$4(0.9)$

$3(0.4)$

Grazing brome (Bromus stamineus)

Gala

25

2009

$8(0.5)$

$0(0)$

Annual grasses

Annual ryegrass (Lolium multiflorum)

Gulf

15

2009

$9(0.8)$

$7(0.9)$

Soft brome (Bromus hordeaceus)

Blando

15

$2009 \quad 13(1.8)$

$5(1.8)$

\begin{tabular}{|c|c|c|c|c|}
\hline \multicolumn{5}{|l|}{ Herbs } \\
\hline \multicolumn{5}{|c|}{ Chicory (Cichorium intybus) } \\
\hline Grouse & 2 & 2009 & $5(1.1)$ & $0(0)$ \\
\hline \multicolumn{5}{|c|}{ Plantain (Plantago lanceolata) } \\
\hline Tonic & 5 & 2009 & $8(1.2)$ & $0(0)$ \\
\hline \multicolumn{5}{|c|}{ Forage brassica (Brassica napus) } \\
\hline Winfred & 5 & 2009 & $12(1.6)$ & $0(0)$ \\
\hline
\end{tabular}

* Hybrid between Eurasian bluebunch wheatgrasses (Pseudoroegneria strigosa) and quackgrass (Elymus repens).
Plots were seeded in early December using an 8-foot-wide Truax Flex II grass drill (Truax Co., New Hope, MN) with an 8-inch row spacing. Seeding rates were based on the recommendations of seed suppliers (table 1). Prior to seeding, weeds were controlled with applications of glyphosate at 2 pints per acre (Roundup WeatherMax, 1.125 pounds acid equivalent per acre). All plots seeded with grasses (but not herbs) were sprayed in late February after seeding with a combination of 2 pints per acre of 2,4-D (Weedar 64, 0.95 pound acid equivalent per acre) and 1 ounce per acre of carfentrazone (Shark EW, 0.015 pound active ingredient per acre) to control broad-leaved weeds in the seeding year only. The herbicides eliminated all broadleaved weed competition from the grass plots during their seedling year. Since all the plots were in a large pasture with a high proportion of both broad-leaved and annual grass weeds, reinvasion potential was uniform across treatments and soil types.

The perennial forages that survived were generally fully established in the second season after seeding. Perennials were considered established when they could not be manually pulled from the ground. Annual forages were considered established in the spring following seeding. Twelve species were seeded in 2009, seven more varieties became available and were seeded in 2010, and three more were seeded in 2012 as they became available.

\section{Cover, productivity data collection}

Annual spring basal cover data was collected at peak standing crop, generally in early June. A total of 10 square-meter quadrats per replication were marked out at intervals of 15 feet, in the center of each plot to reduce edge effects. Quadrat measurements included percentage basal cover estimates of seeded species, nonseeded species and bare ground. In 2014, we added measurements of annual grass and yellow starthistle (Centaurea solstitialis L.) cover, and we recorded the entire species composition of the control plots. At the center of each square-meter quadrat, the number of seeded plants in a 1-square-foot quadrat were counted.

In 2010 and 2012, production of the seeded forage plants (not of any other plants present) was measured in each 1-square-foot quadrat using the comparative yield method (George et al. 2009). In 2014, production was measured in every other 1-foot-square quadrat, for a total of five quadrats per replication, with the intention of determining smaller differences in biomass between forages. Again, only the seeded species in each quadrat was clipped and weighed. In the control plots, in both cases, all species were included in production measurements. Samples were weighed and recorded after being oven dried at $130^{\circ} \mathrm{F}$ for 36 hours. Final weights were recorded when samples were considered fully dry, the point at which weights no longer continued to decrease with drying. 


\section{Grazing periods}

All plots were grazed annually, toward the end of the dormant summer season to prevent thatch buildup. Grazing was completed concurrently on each site using 15 nonlactating beef cows for 2 to 5 days depending on the amount of forage present in each plot. Grazing ceased when forage was estimated to be approximately 500 pounds per acre dry matter during each event. Since grazing continued until all plots were grazed to a uniform level, estimates of animal preference for particular forages was not credible, but equal comparisons of forage persistence after grazing were possible because they were all grazed equally.

In 2011 and 2013, all plots were flash grazed in late winter and again in spring prior to data collection, so we did not measure forage production in those years. In these two seasons, grazing ceased 30 to 45 days before cover monitoring to allow potential seed production of annuals, as well as perennial plant recovery and survival of the summer dormant season (Cullen et al. 2005; Ogden and Loomis 1972). Grazing the plots during the growing season allowed us to evaluate their resilience to grazing, which is an important component in their potential applicability to improve grazed rangelands.

\section{Data analysis}

Because cover data was collected systematically each year (and the production data in only two of the years), we focused our analysis on the cover data. We started with a generalized linear mixed model (GLMM, Poisson distribution) to investigate the contribution of species variety and soil type (Arbuckle and Tehama) on percentage cover. To address differences in environmental conditions across seeding years, varieties seeded in 2009 and 2010 were analyzed using different models. Varieties seeded in 2012 failed to establish and were thus excluded from further analysis. The model for species seeded in 2009 included the fixed factors of seeded variety, life cycle (annual or perennial) and soil type, as well as random factors subplot $(n=10)$ nested in replicate $(n=3)$ and year monitored (to account for repeated measures).

Results from the 2009 variety model suggested that data describing annuals and perennials should be investigated separately. Subsequently, we developed two models on the 2009 seeded species data - one for annual species only and one for perennial species only. Each of these models included the fixed factors of seeded variety, year monitored and soil type, as well as random factors subplot nested in replicate. The model for species seeded in 2010 included the fixed factors of seeded variety, year monitored and soil type (only perennial species were seeded in 2010 , so we did not need to include life cycle as a factor), as well as random factors subplot nested in replicate.

In the field, it is sometimes suggested by range professionals and ranchers that the percentage of bare ground, rather than weed cover, most affects perennial grass spread (i.e., greater cover) or establishment. To understand the strength of the relationship between percentage cover of forage species and bare ground and between percentage cover of forage species and weeds, we conducted correlation tests. The data was again separated by year seeded (2009 or 2010) and, within 2009, by life cycle (annual and perennial). All analyses were conducted in $\mathrm{R}$ version 3.2.2 using the lme4 package ( $\mathrm{R}$ Development Core Team 2008).

\section{Results}

Soil type did not contribute to significant differences in cover across varieties seeded in 2009 ( $p=0.25$ ) or for varieties seeded in 2010 ( $p=0.12$ ). However, some varieties demonstrated idiosyncratic differences in cover in response to the different soil types through time. For example, the orchardgrasses Berber and Paiute both demonstrated significantly lower cover on Tehama soil than on Arbuckle soil (a 15\% difference in cover for Berber and a $28 \%$ difference in cover for Paiute). There was also no difference between the cover of annuals (mean cover $=40.73 \%, \mathrm{SE}=12.8$ ) and perennials (mean

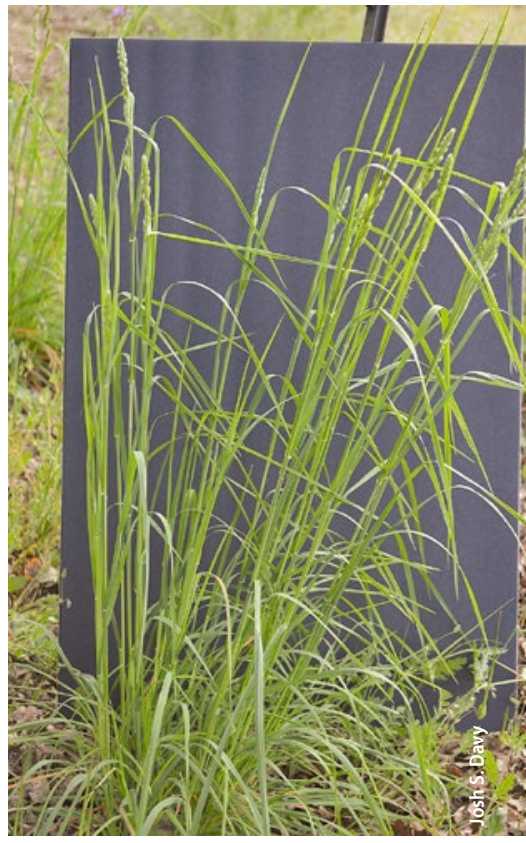

Established Berber orchardgrass (May 2013). By 2014, the Berber grass plot was almost 3 times more productive than the unseeded control plot. In addition, of the three orchardgrass varieties tested, only Berber survived the hot, dry summer.

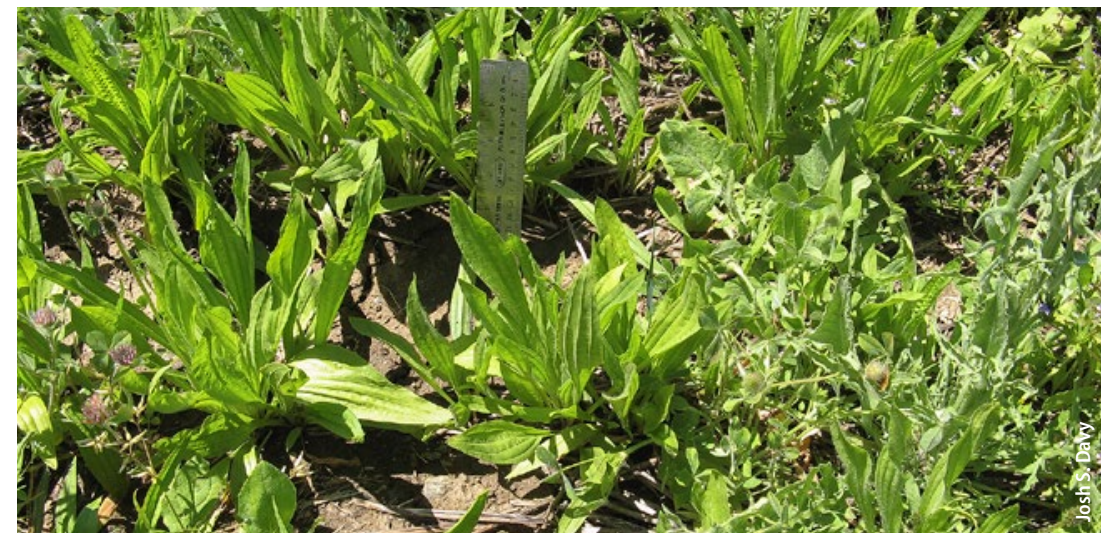

Tonic plantain, a perennial herb, at the end of the first growing season. Trial results suggest that the herb species are best utilized as short rotations before another crop or when high quality forage is needed for the short term.

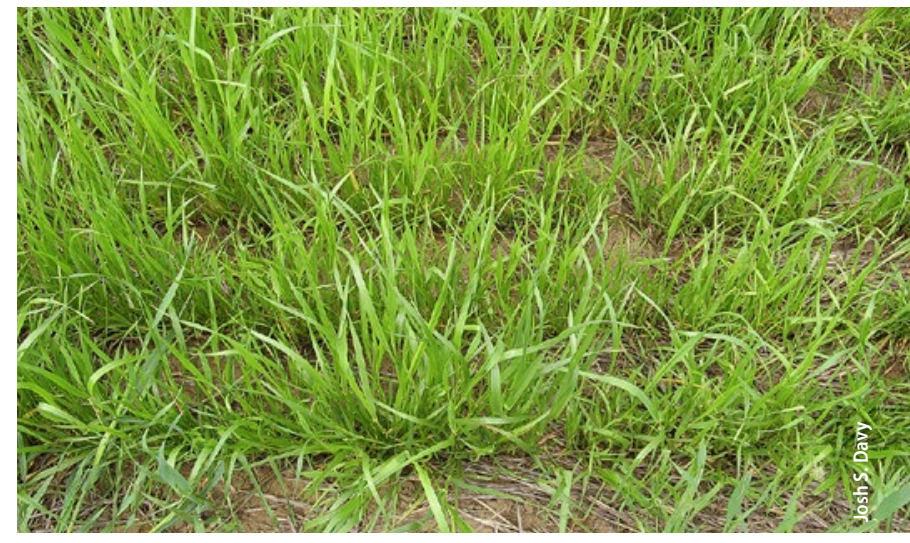

Gulf annual ryegrass established vigorously during its seeding year (April 2010). 
Fig. 1. Mean percentage cover (\%) \pm SE of annual forage species by soil type.
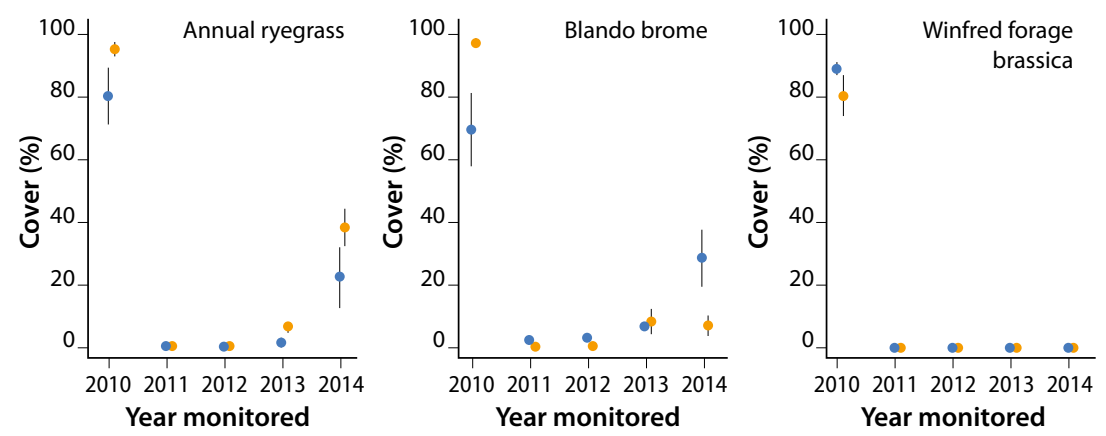

- Arbuckle soil - Tehama soil

TABLE 2. Production (lb/ac dry matter) of seeded forages, 2010 and 2014, and of all species in the control plots, 2014

\begin{tabular}{|c|c|c|}
\hline \multirow{3}{*}{ Forage species, varieties } & \multicolumn{2}{|c|}{ Dry matter } \\
\hline & 2010 & 2014 \\
\hline & \multicolumn{2}{|c|}{$\mathrm{Ib} / \mathrm{ac}(\mathrm{SE})$} \\
\hline Gala brome & $1,416(172)$ & $0(0)$ \\
\hline Grouse chicory & $1,188(277)$ & $0(0)$ \\
\hline Winfred forage brassica & $1,802(300)$ & $0(0)$ \\
\hline Blando brome & $2,590(458)$ & 394 (309) \\
\hline Annual ryegrass & $8,669(772)$ & $2,870(481)$ \\
\hline Nordan crested wheatgrass & $N A^{*}$ & $0(0)$ \\
\hline Tonic plantain & NA & $0(0)$ \\
\hline Paiute orchardgrass & NA & $0(0)$ \\
\hline Kara orchardgrass & NA & $0(0)$ \\
\hline Control & & $1,596(266)$ \\
\hline Luna pubescent wheatgrass & NA & $1,725(587)$ \\
\hline Rush intermediate wheatgrass & NA & $2,514(788)$ \\
\hline Australian II hardinggrass & NA & $2,538(910)$ \\
\hline Anderson blue wildrye & NA & $3,047(891)$ \\
\hline Berber orchardgrass & NA & $4,369(1,219)$ \\
\hline Alkar tall wheatgrass & NA & $4,572(1,160)$ \\
\hline Perla koleagrass (hardinggrass) & NA & $4,970(808)$ \\
\hline Holdfast hardinggrass & NA & $5,155(954)$ \\
\hline Flecha tall fescue & NA & $5,302(963)$ \\
\hline Advanced AT hardinggrass & NA & $6,366(1,729)$ \\
\hline
\end{tabular}

than on Arbuckle soil (mean cover $=63.51 \%, \mathrm{SE}=9.10$; estimate $=-0.22, \mathrm{SE}=0.03, p<0.001)$.

Although most perennial varieties seeded in 2009 decreased in cover through time (fig. 2), several hardinggrass varieties, including Perla koleagrass (estimate $=0.199, \mathrm{SE}=0.02, p<0.001)$, and Flecha tall fescue (estimate $=0.21, \mathrm{SE}=0.02, p<0.001$ ) either maintained or increased cover through time. The varieties that performed the best in the short term (i.e., between 1 and 3 years after seeding), which included Gala brome (mean cover $=78.05 \%, \mathrm{SE}=5.5$ ), Grouse chicory (mean cover $=79.85 \%, \mathrm{SE}=8.1$ ) and Tonic plantain (mean cover $=79.8 \%$, SE $=7.7$ ), were unable to maintain cover well. The varieties that demonstrated the best cover for multiple years were Berber orchardgrass (mean cover $=58.3 \%, \mathrm{SE}=10.3$ ), Flecha tall fescue (mean cover $=57.48 \%, \mathrm{SE}=10.6)$ and Perla koleagrass (mean cover $=65.03 \%$, SE $=9.3$ ).

Although the overall cover of varieties seeded in 2010 did not change through time (estimate $=-0.07$, $\mathrm{SE}=0.10, p=0.48$; fig. 2 ), some varieties, such as Advanced AT (estimate $=0.18, \mathrm{SE}=0.01, p<0.001$ ), did increase in cover through time. We also found that varieties seeded in 2010 demonstrated idiosyncratic differences in cover in response to the different soil types. For example, Advanced AT (estimate $=0.18, \mathrm{SE}=0.02$, $p<0.001$ ) and Australian II hardinggrasses (estimate $=0.44, \mathrm{SE}=0.04, p<0.001)$ consistently demonstrated better cover on the Tehama soil through time (fig. 2). Although Luna pubescent wheatgrass was the forage that performed best in the short term (mean cover = $50.8 \%, \mathrm{SE}=6.05)$, Holdfast hardinggrass performed the best overall (mean cover $=51.9 \%, \mathrm{SE}=10.7$ ).

As might be expected, forage production (table 2) was positively correlated with percentage cover for both annual $(r=0.53, t=9.29, p<0.001)$ and perennial forage species $(r=0.61, t=33.86, p<0.001)$. Average invasive annual grass and yellow starthistle cover also differed among the forage seeding treatments (tables 3 and 4). For forage annuals seeded in 2009, there was a negative correlation between bare ground and forage cover $(r=-0.49, t=-9.43, p<0.001)$, as well as between weed cover and forage cover $(r=-0.66, t=-9.48, p<$ 0.001 ). For forage perennials seeded in 2009 and 2010 , there was a negative correlation between bare ground and forage cover $(2009 r=-0.41, t=-7.85, p<0.001$, and $2010 r=-0.12, t=-2.48, p=0.01)$, as well as between weed cover and forage cover $(2009 r=-0.84, t=$ $-26.93, p<0.001$, and $2010 r=-0.82, \mathrm{t}=-29.53, p<$ $0.001)$

\section{Clear differences in cover, production}

We considered a forage variety successful if it produced a stand of $50 \%$ ground cover, thus expressing its relative dominance over all other species. Clear differences were obvious in the performance of annual vs. perennial forage varieties in providing forage (cover and 
production) from a single seeding in the short term ( 1 to 3 years) and long term ( $>3$ years). To maintain the stand of any of the seeded annuals in the trial, even the reseeding varieties, we suggest resowing within a few years, which has been suggested elsewhere (Papanastasis 1976).

\section{Performance of annual grass species}

Because the annual grass varieties Blando brome and Gulf annual ryegrass provided high cover and production quickly, they appear to be good candidates for forage in the year they are seeded (fig 1., table 2). Blando brome does not appear to be as productive as annual ryegrass.

Though a robust stand in terms of cover never occurred from annual ryegrass reseeding, as a volunteer stand in subsequent years, annual ryegrass cover in the seeded plots was double the annual ryegrass cover in the control and produced 1,274 pounds per acre dry matter in 2014 (2,870 pounds per acre vs. 1,596 pounds per acre dry matter, table 2 ). Although both annual grasses in the trial were capable of producing seeds for germination in subsequent years, sustained cover after the seeding year was unreliable, difficult to differentiate from the natural seedbank and always below our target of a dominant stand that exceeds $50 \%$ cover.

\section{Performance of herb forage species}

The annual herb Winfred forage brassica produced a robust stand in the year of seeding but should be considered a single-season crop due to its lack of seed production. We would not expect this forage to have enough time to mature and produce seeds in a dryland situation.

Perennial herbs Tonic plantain and Grouse chicory established well the first year, with some plants surviving into the second season. Although the surviving second-year plants looked healthy early in the season, almost no plants were evident in the third season. When the surviving herbs were grazed in the second season (2010-2011), they did not appear to recover and regrow, which made us speculate that the herbs were best suited to a single-harvest situation. The herb species appear to be options for a short rotation before another crop, or when a high-quality source of forage is needed for the short term.

\section{Performance of perennial forage species}

None of the perennial forage varieties investigated in this study established fast enough to be grazed in their seedling year. In management scenarios, perennial grass forage production should be considered zero in the first year, as stands appear to be easily damaged by grazing during establishment. This could be due to the slow growth rate of seedling perennials compared to

Fig. 2. Mean percentage cover (\%) $\pm \mathrm{SE}$ through time of perennial forage species seeded in 2009 and 2010 by soil type.
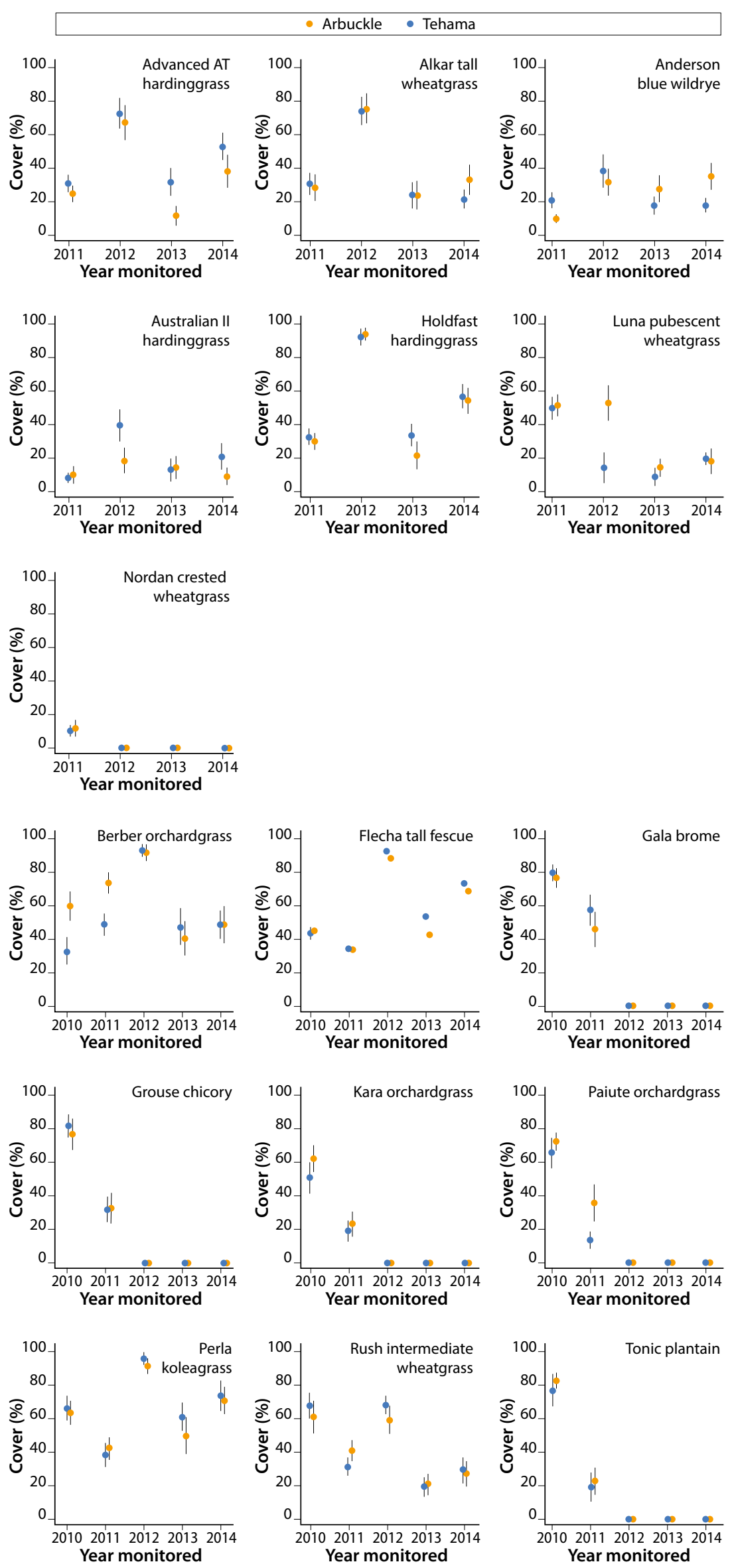


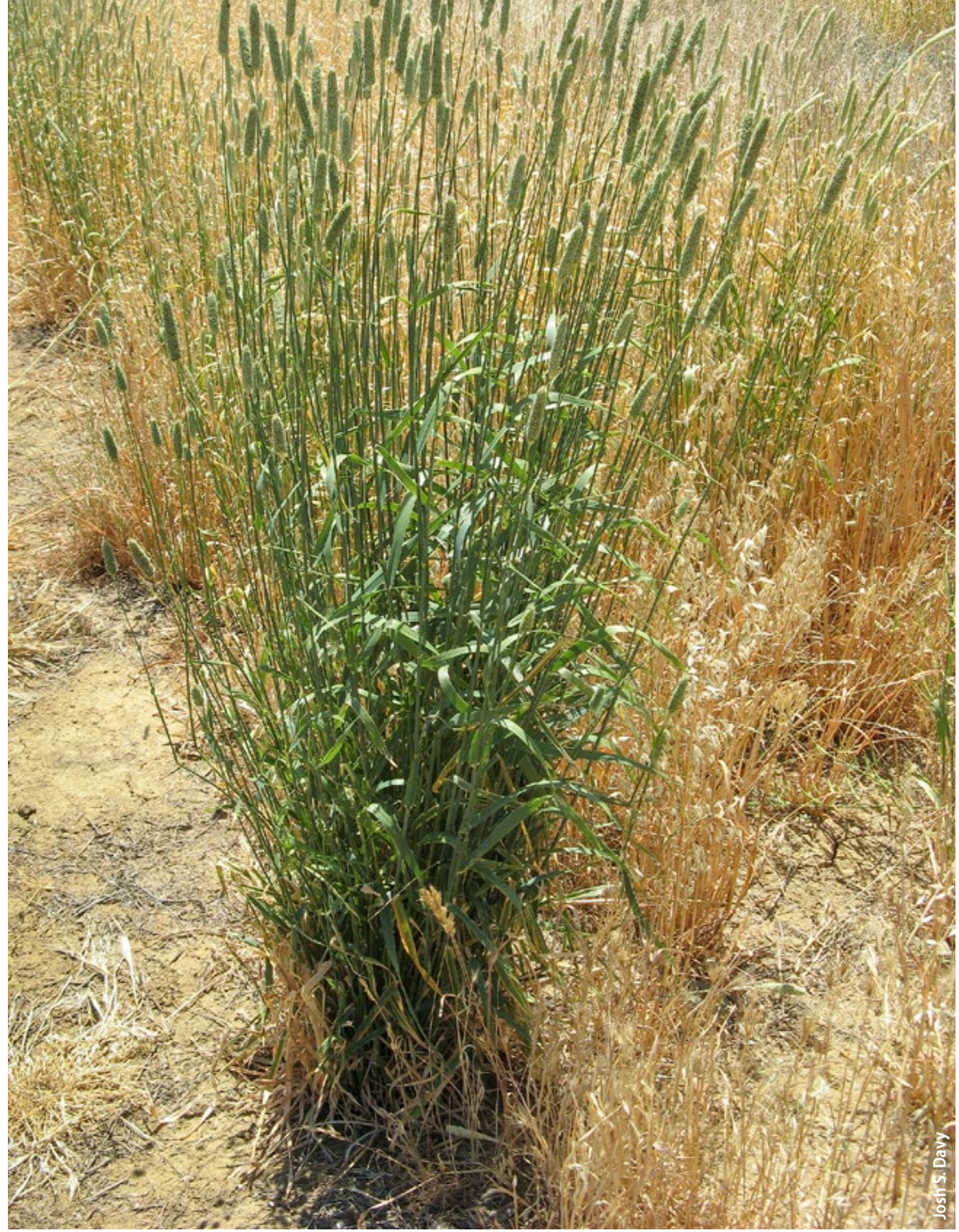

Holdfast hardinggrass, a perennial developed in Australia, proved to be a viable replacement for Perla koleagrass if Perla seeds are not available.

seedling annuals (Garnier 1992), which causes seedling perennials to be easily uprooted prior to establishment. Although withholding grazing the first year of a perennial seeding will enhance establishment, the loss of a season of grazing incurs a substantial cost (USDA NASS 2013) and must be considered in ranch planning.

If the grazing deferment period can be tolerated, perennial grasses provide a more stable ground cover for a longer period than annuals. They also produce abundant forage. In 2014, the six top-producing perennial grasses ranged from nearly three (Berber orchardgrass) to four (Advanced AT hardinggrass) times more productive than the unseeded control (table 2). We found this increased forage production particularly impressive because, unlike the sampling in the control, which included weighing all plants in the quadrat, sampling of the seeded quadrats included only the weight of the seeded forage species, and excluded all other species.

Most perennial seedings looked successful at the completion of the seedling year, but they did not all survive the first summer. Although we did not quantify summer dormancy, we assumed failed forages did not exhibit enough summer dormancy to survive, in contrast to those that successfully maintained a stand into the second year. For example, the failure of Paiute orchardgrass (fig. 2) was unexpected because
The six top-producing perennial grasses ranged from nearly three (Berber orchardgrass) to four (Advanced AT hardinggrass) times more productive than the unseeded control.

it appeared to have good seedling vigor and has been recommended for seeding in semi-arid dryland situations (Monsen and Stevens 1985). Of the three orchardgrass varieties tested, only Berber survived the hot, dry summer of this California foothills region. Likewise, though Gala brome is considered a perennial species for drought areas (Stewart 1992), individual plants did not survive their first summer. Gala did produce an abundance of seeds, giving it the capacity to regenerate a stand in the short term (second year only).

Like Norton et al. (2006), we found that Flecha tall fescue displayed enough summer dormancy to survive the rainless summer. To our knowledge, this is the first test of Flecha tall fescue in California, though it has been tested in the Southern Great Plains (Malinowski et al. 2005). Results from our study suggest that Flecha fescue appears to be highly productive, producing 3.3 times more forage than the unseeded control. It should be considered a viable candidate for improving California rangelands if a perennial grass is desired.

We found all of the hardinggrass varieties adequately adapted for summer survival, with seedings of Perla koleagrass, Advanced AT and Holdfast all successful and highly productive. Even though Australian II did not produce the $50 \%$ ground cover we considered necessary for a successful stand, the stand remained stable after the first year (fig. 2), though it did not produce any more forage than the unseeded control in 2014. Perla koleagrass was developed in California by the California Agricultural Experiment Station and USDA (USDA SCS 1985), which has made it the most commonly planted cultivar of hardinggrass, although seed is not available every year. In the absence of adequate Perla koleagrass seed, Australian-bred varieties Holdfast and Advanced AT appear to be viable replacement options.

The only native perennial grass tested was Anderson blue wildrye. The blue wildrye stand had the same number of plants per square foot in 2014 as Perla koleagrass, Berber orchardgrass and Flecha tall fescue (table 1), but it never reached our target of $50 \%$ cover of the seeded forage (fig. 2). This could be due to its upright (rather than bunching) growth habit. Blue wildrye plants survived well; however, we are not confident in the ability of blue wildrye, seeded alone, to suppress weed invasion, especially compared to the other perennials, which were able to sequester more ground cover (table 3). Blue wildrye produced significantly less forage 
than the top six nonnative perennial grasses; however, it still produced nearly double the amount of forage as the control in 2014 (3,047 pounds per acre compared to 1,596 pounds per acre dry matter, respectively; table 2).

The utility of wheatgrass varieties for forage is limited by their season of growth. Unlike the results from trials in higher elevation areas (Enloe et al. 2005), results from our study in California foothill rangelands suggest that wheatgrass varieties should not be used for short- or long-term forage cover. Only Alkar tall, Luna pubescent and Rush intermediate wheatgrasses even produced initial stands, and these declined once grazed. Of all the perennial wheatgrasses seeded, only Alkar tall produced more forage than the unseeded control in 2014, which we attribute to a relatively high dry matter weight of individual plants because the stand lacked robust cover.

Seeding of crested wheatgrass varieties failed to produce a single successful stand. We suspect that their late spring and early summer growing season did not match this climate. It is likely that moisture was limited during early summer, at their peak growth phase. They germinated, but the plants failed to survive the first summer. Borman et al. (1991) documented that the lack of fall and winter growth of crested wheatgrass varieties makes them highly susceptible to annual grass invasion (table 3). In accordance with findings by Borman et al. (1991), we found the most successful perennial grasses commenced growth early in the fall, continued through winter and peaked in late spring.

\section{Ability of forage seedings to prevent weed invasion}

Perennial grasses differed in their ability to prevent the invasion of annual grasses. During the 2014 season, we monitored the percentage cover of annual grasses that had encroached into the perennial plots (table 3). No seeded forages entirely prevented annual grass invasion, but several clearly limited invasion. Annual grass invasion into perennial grass plots ranged from $22 \%$ to $73 \%$ of the plot area. Surprisingly, invasion of annual grasses into established perennial grass stands was not largely different from, and even slightly less than, recorded by Borman et al (1991). For example, our annual grass invasion into Berber orchardgrass was $37 \%$ compared to their $44 \%$, and into tall wheatgrass
TABLE 4. Yellow starthistle cover (\%) in forage plots, 2014

\begin{tabular}{|l|l|l|}
\hline & \multicolumn{3}{|c|}{ Yellow starthistle cover } \\
\hline Forage species, varieties & $\%$ & $S E$ \\
\hline Holdfast hardinggrass & 0 & 0 \\
\hline Flecha tall fescue & 0 & 0 \\
\hline Berber orchardgrass & 0 & 0 \\
\hline Perla koleagrass & 0 & 0 \\
\hline Australian II hardinggrass & 0.10 & 0.10 \\
\hline Rush intermediate wheatgrass & 0.10 & 0.20 \\
\hline Advanced AT hardinggrass & 0.10 & 0.23 \\
\hline Anderson blue wildrye & 0.25 & 0.61 \\
\hline Luna pubescent wheatgrass & 0.33 & 0.65 \\
\hline Alkar tall wheatgrass & 0.50 & 0.71 \\
\hline Blando brome & 7.00 & 5.87 \\
\hline Annual ryegrass & 11.90 & 6.71 \\
\hline Control & 15.50 & 5.00 \\
\hline
\end{tabular}

it was $58 \%$ compared to their $65 \%$. We found this very encouraging in terms of the success of our seeding in a production environment that was far less optimal than the transplanting method used in the Borman et al.

(1991) study.

In 2014, we also recorded yellow starthistle cover. Of particular interest was the ability of all perennial forage species to suppress yellow starthistle (table 4), including those that showed almost no suppression of annual grass invasion. Yellow starthistle cover was nearly zero in all of the established perennial grass plots even though the abundance of yellow starthistle around the plots made the opportunity of invasion clearly evident. Gulf annual ryegrass and Blando brome were not as successful at preventing yellow starthistle invasion, which was significant because they had been seeded in the same manner as the perennial grasses, creating an equal comparison to evaluate resistance to invasion. This data suggests that seeding perennial grasses, rather than annual grasses, is a viable management approach to controlling yellow starthistle in Northern California's Mediterranean climate.

\section{Effect of soil type}

In these trials, soil type had little effect on overall production and cover, suggesting that although the two soil types differed in available water storage, both were adequate for growth of annual and perennial forages. This was unexpected because different soils are typically characterized by dissimilar moisture, chemical and mycorrhizal content, which can directly affect forage production (e.g., Bennett and Doss 1960; Lambert and Cole 1979). However, because we did identify some variety-specific soil responses, further research in annual rangeland systems that tests these forage species 
in different soil types, including shallower soils, would be of value.

\section{Short- and long-term recommendations}

Life cycle (annual or perennial) should be the primary consideration in determining suitable forage choices for either the short or long term. It is not recommended to seed perennial and annual grasses simultaneously. However, if the addition of annuals is desired, sowing them after the perennial grasses are established would ensure the perennials are not outcompeted during the seedling stage (Lodge 2000).

In cases where short-term forage production and weed suppression are management priorities, this work suggests that annual ryegrass and/or soft brome are the most viable options. For longer-term production without reseeding, best forage candidates are mostly perennials, including Flecha tall fescue, hardinggrass (Perla koleagrass, Holdfast, Advanced AT) or Berber orchardgrass, as a mix or a monoculture. CA

J.S. Davy is UC Cooperative Extension (UCCE) Livestock and Range Advisor in Tehama, Glenn and Colusa counties; T. Turri is Owner and Manager of Turri Family Farms; K. Dykier is UC Davis Graduate Student; and E. Gornish is Cooperative Extension Specialist at the University of Arizona.

We thank the following vendors for their support of this research through the donation of seeds and herbicides necessary for completing the trials: Wilbur Ellis (JJ Gross, Colusa, California), Kellogg Ag Service (Bill Kellogg, Paradise, California), Kamprath Seed (Tom Johnson, Manteca, California) and PGG Seed (John Snider, California and Oregon). We also thank Larry Galper of Elk Flat Ranch.

\section{References}

Adams T, Vaughn C, Sands P. 1999. Geographic races may exist among perennial grasses. Calif Agr 53:33-8.

Bennett OL, Doss BD. 1960 Effects of soil moisture level on root distribution of coolseason forage species. Agron $J$ 52:204-7.

Blank RR, Morgan T, Allen F. 2015. Suppression of annual Bromus tectorum by perennial Agropyron cristatum: Roles of soil nitrogen availability and biological soil space. AoB PLANTS 7:plv006.

Borman MM, Krueger WC Johnson DE. 1991. Effects of established perennial grasses on yields of associated annual weeds. J Range Manage 44:318-22.

[CDC] California Department of Conservation. 2014. Statistical Summaries and Reports. www. conservation.ca.gov/dlrp/ fmmp/trends/Pages/Index.aspx (accessed Feb. 4, 2015).

Cullen BR, Chapman DF, Quigley PE. 2005. Persistence of Phalaris aquatica in grazed pastures 2. Regenerative bud and tiller development. Aust J Exp Agr 45:49-58.

Enloe SF, DiTomaso JM, Orloff SB, Drake DJ. 2005. Perennial grass establishment integrated with clopyralid treatment for yellow starthistle management on annual range. Weed Technol 19:94-101.

Garnier E. 1992. Growth analysis of congeneric annual and perennial grass species. J Ecol 80:665-75.
George MR, Barry SJ, Larson SR, et al. 2009. Comparison of comparative yield and stubble height for estimating herbage standing crop in annual rangelands. Rangeland Ecol Manag 59:438-41.

James JJ, Gornish ES, DiTomaso JM, et al. 2015. Managing medusahead (Taeniatherum caput-medusae) on rangeland: A meta analysis of control efforts and assessment of stakeholde needs. Rangeland Ecol Manag 37:135-7.

Jankauskas B, Jankauskiene G. 2003. Erosion preventive crop rotations for landscape ecological stability in upland regions of Lithuania. Agr Ecosyst Environ 95:129-42.

Kay B. 1969. Hardinggrass and annual legume production in the Sierra foothills. J Range Manage 22:174-7.

Lambert DH, Cole H. 1979.

Effects of mycorrhizae on es-

tablishment and performance of forage species in mine spoil. Agron J 2:257-60.

Lodge GM. 2000. Competition among seedlings of perennial grasses, subterranean clover, white clover, and annual ryegrass in replacement series mix tures. Aust J Agr Res 51:377-84.

Love RM. 1951. Range grass and reseeding experiments in California: Complexity of range improvement problem requires long-term research program involving allied fields of study. Calif Agr 5:8-10.

Love RM, Osterli VP, Berry LJ. 1953. Hardinggrass for reseeding: Dryland pasture seed mixture improved by addition of hardy perennial grass palatable to livestock. Calif Agr 7:5-12.
Malik RK, Green TH, Brown GF, Mays D. 2000. Use of cover crops in short rotation hardwood plantations to control erosion. Biomass Bioenerg 18:479-87.

Malinowski DP, Zuo H, Kramp BA, et al. 2005. Obligatory summer-dormant cool-season perennial grasses for semiarid environments of the Southern Great Plains. Agron J 97:147-54.

Mapfumo E, Naeth MA, Baron VS, et al. 2002. Grazing impacts on litter and roots: Perennial versus annual grasses. J Range Manage 55:16-22.

McKell CM, Whalley RD, Brown V. 1966. Yield, survival, and carbohydrate reserve of hardinggrass in relation to herbage removal. J Range Manage 19:86-9.

Miller HW, Hafenrichter AL, Hoglund OK. 1957. The influence of management methods on seedings of perennials in the annual range area. J Range Manage 10:62-6.

Miller HW, Hoglund OK, Hafenrichter AL. 1953. Reseeding to aid conservation of annua forage range. J Range Manage 6:414-22.

Monsen SB, Stevens R. 1985. 'Paiute' orchardgrass - forage species for semi-arid range and wildland sites. Rangelands 7:114-5

Norton MR, Lelievre F, Volaire F. 2014. Measuring dehydration tolerance in pasture grasses to improve drought survival Crop Pasture Sci 65:828-40.
Norton M, Volaire F, Lelievre F. 2006. Summer dormancy in Festuca arundinacea Schreb: The influence of season on sowing and a simulated mid-summer storm on two contrasting cultivars. Aust J Agr Res 57:1267-77.

Ogden PR, Loomis WF. 1972 Carbohydrate reserves of intermediate wheatgrass after clipping and etiolation treatments. J Range Manage 25:29-32.

Papanastasis V. 1976. Factors involved in the decline of annual ryegrass seeded on burned brushlands in California. J Range Manage 29:244-7.

PRISM. 2016. PRISM Climate

Group. www.prismclimate.org (accessed Aug. 17, 2016).

R Development Core Team. 2008. R: A Language and Environment for Statistica Computing. Vienna, Austria: R Foundation for Statistical Computing. ISBN 3-900051-07-0. www.R-project.org.

Reed KFM, Nie ZN, Miller SM, et al. 2008. Field evaluation of perennial grasses and herbs in southern Australia. 1. Establishment and herbage production. Aust J Exp Agr 48:409-23. Roche Jr. BF, Roche CT, Chapman RC. 1997. Impacts of grassland habitat on yellow starthistle (Centaurea solstitialis L.) invasion. Northwest Sci 68:86-96.

Rose KK, Hild AL, Whitson T, et al. 2001. Competitive effects of cool-season grasses on re-establishment of three weed species. Weed Technol 15:885-91. Sanderson MA, Labreveux $M$, Hall MH, Elwinger GF. 2003. Forage yield and persistence of chicory and English plantain. Crop Sci 43:995-1000.
Stebbins G. 1950. New grasses: Drought-resistant strains of perennials developed for dry range lands. Calif Agr 4:5-10.

Stewart AV. 1992. 'Grasslands Gala' grazing brome (Bromus stamineus Desv.) - a new dryland pasture grass. New Zeal J Agr Res 35:349-53.

[USDA NASS] US Department of Agriculture Economic Research Service and National Agriculture Statistics Service. 2013. 2013 California Land Values and Cash Rents. www.nass. usda.gov/Statistics by State/ California/Publications/Other Files/2013/201309IndvIscshrnts. pdf (accessed Feb. 9, 2015, Aug. 10, 2015).

[USDA NRCS] USDA Natural Resources Conservation Service. 2015. Web Soil Survey. http:// websoilsurvey.sc.egov.usda. gov/App/HomePage.htm (accessed Feb. 9, 2015)

[USDA SCS] USDA Soil Conservation Service. 1985. 'Perla' Koleagrass. Davis, California.

Whitson TD, Koch DW. 1998. Control of downy brome (Bromus tectorum) with herbicides and perennial grass competition. Weed Technol 12:391-6. Wiedenhoeft MH. 1993. Management and environment effects on dry matter yields of three Brassica species. Agron 85:549-53.

Wilson RG, Orloff SB, Lancaster $\mathrm{DL}$, et al. 2010. Integrating herbicide use and perennial grass revegetation to suppress weeds in noncrop areas. Invas Plant Sci Mana 3:81-92. 